\title{
EKSPLORASI ETNOMATEMATIKA RUMAH GADANG MINANGKABAU SUMATERA BARAT
}

\author{
Yulia Rahmawati $\mathbf{Z}^{1)^{*}}$, Melvi Muchlian²) \\ ${ }^{1)}$ Universitas Tamansiswa Padang, Jl. Tamansiswa No 9, 25138 \\ ${ }^{2)}$ Universitas Tamansiswa Padang, Jl. Tamansiswa No 9, 25138 \\ *yulia_rahmawatiz@ymail.com
}

\begin{abstract}
Abstrak
Pendidikan dan budaya adalah sesuatu yang tidak bisa dipisahkan dalam kehidupan seharihari. Etnomatematika hadir untuk menjembatani antara budaya dan pendidikan khususnya pembelajaran matematika. Tanpa disadari masyarakat telah melakukan berbagai aktivitas dengan meggunakan konsep dasar matematika dan ide-ide matematis. Misalnya, aktivitas berhitung dengan menyebutkan suatu bilangan, aktivitas mengukur (panjang, luas, volume, dan berat), kesenian, permainan, aktivitas jual beli (menghitung uang kembalian, laba atau rugi, dan sebagainya), dan arsitektur bangunan (Rumah Adat). Penelitian ini bertujuan untuk mengkaji dan menganalisis eksplorasi etnomatematika Rumah Gadang Minangkabau Sumatera Barat agar diperoleh informasi dasar dalam pengembangan ilmu etnomatematika terhadap pembelajaran matematika bidang geometri khusus pada bentuk dan ukiran rumah gadang minangkabau. Jenis penelitian ini adalah penelitian eksploratif dengan menggunakan pendekatan etnografi dengan analisis taksonomi. Berdasarkan hasil penelitian yang dilakukan, terdapat unsur dan konsep matematika yang digunakan dalam melakukan aktivitas pembuatan rumah gadang minangkabau. Tanpa mempelajari teori tentang konsep-konsep matematika tersebut, masyarakat Minangkabau telah menerapkan konsep matematika dalam kehidupan sehari-hari. Terbukti adanya bentuk etnomatematika masyarakat minangkabau yang tercermin melalui berbagai hasil aktivitas matematika yang dimiliki dan berkembang di masyarakat minangkabau, meliputi: 1) aktivitas membuat rancangan pembangunan rumah gadang; dan 2) aktivitas membuat pola ukiran pada motif ukiran dinding rumah gadang.
\end{abstract}

Kata Kunci: Etnomatematika, Rumah Gadang, Geometri, Eksploratif, Etnografi. 


\section{PENDAHULUAN}

Pendidikan dan budaya adalah sesuatu yang tidak bisa dipisahkan dalam kehidupan sehari-hari. Pendidikan merupakan kebutuhan mendasar bagi setiap individu dalam masyarakat sedangkan budaya merupakan kesatuan utuh dan menyeluruh yang berlaku dalam suatu masyarakat, nilai dan idenya dihayati oleh sekelompok manusia di suatu lingkungan hidup tertentu dan disuatu kurun waktu tertentu. Menurut E. B. Tylor budaya merupakan keseluruhan aktivitas manusia, termasuk pengetahuan, kepercayaan, seni, moral, hukum, adatistiadat, dan kebiasaan-kebiasaan lain (Ratna, 2005). Sedangkan menurut ilmu antropologi, budaya merupakan keseluruhan sistem gagasan, tindakan, dan hasil karya manusia dalam rangka kehidupan masyarakat yang dijadikan milik diri manusia dengan belajar (Koentjaraningrat, 1985). Hal ini berarti bahwa hampir seluruh aktivitas manusia merupakan budaya atau kebudayaan karena hanya sedikit sekali tindakan manusia dalam rangka kehidupan masyarakat yang tidak memerlukan belajar dalam membiasakannya. Sedangkan ahli sejarah budaya mengartikan budaya sebagai warisan atau tradisi suatu masyarakat. Ilmu matematika sudah menjadi bagian dari kebudayaan manusia. Namun, sebagian besar masyarakat sering tidak menyadari bahwa mereka telah menerapkan ilmu matematika dalam kehidupan sehari-hari. Mereka memandang bahwa matematika hanyalah suatu mata pelajaran yang dipelajari di bangku sekolah.

Berdasarkan hasil studi dari TIMSS (Trends in International Mathematics and Science Study) pada tahun 2011, Indonesia berada pada urutan yang sangat rendah di bawah rata-rata dan jauh tertinggal dari negara tetangga seperti Singapura, Malaysia dan Thailand. Hal ini disebabkan kurangnya pemahaman siswa dalam penalaran dan pemecahan masalah sehingga siswa kurang mampu menyelesaikan soal-soal yang berkaitan dalam penalaran dan pemecahan masalah khususnya pada permasalahan geometri. Selain itu, berdasarkan fakta di masyarakat, belajar hanya sebagai tolak ukur untuk mencapai nilai saja bukan berdasarkan bagaimana siswa itu memahami dan menyelesaikan permasalahan yang diberikan. Padahal, dalam kehidupan bermasyarakat siswa tidak menyadari bahwa selama ini mereka sudah menerapkan ilmu matematika di dalam kehidupannya.

Wahyuni, et.al (2013) mengatakan bahwa salah satu yang dapat menjembatani pedidikan dan budaya khususnya pendidikan matematika adalah etnomatematika. Tanpa disadari masyarakat telah melakukan berbagai aktivitas dengan meggunakan konsep dasar matematika dan ide-ide matematis. Misalnya, aktivitas berhitung dengan menyebutkan suatu bilangan, aktivitas mengukur (panjang, luas, volume, dan berat), kesenian, permainan, aktivitas jual beli (menghitung uang kembalian, laba atau rugi, dan sebagainya), dan arsitektur bangunan (Rumah Adat). Konsep dasar tersebut telah mereka pelajari di bangku sekolah dasar. Ide-ide matematis mulai dipandang oleh para ahli pendidikan matematika sebagai suatu hal yang penting. Sifat matematika cenderung linier dan kaku tetapi apabila diintegrasikan dengan sesuatu yang soft seperti budaya, maka pemikiran itu menjadi lentur.

Indonesia merupakan salah satu negara yang memiliki berbagai macam kebudayaan, suku, ras, dan rumah adat. Salah satunya adalah Sumatera Barat yang memiliki rumah adat yang disebut rumah adat Minangkabau atau yang biasa disebut dengan Rumah Gadang. Rumah Gadang adalah salah satu kekayaan budaya 
FIBONACCI : Jurnal Pendidikan Matematika dan Matematika. Vol. ( ), pp: .

Indonesia yang perlu dilestarikan. Kini jumlah rumah gadang yang terdapat di Sumatera Barat semakin lama semakin sedikit.

Rumah gadang banyak tersebar di daerah Sumatera Barat terutama yang terkenal di daerah Batusangkar yaitu Rumah Gadang Istano Basa Pagaruyung dan di daerah Solok Selatan yang disebut negeri 1000 rumah gadang. Rumah Gadang Istano Basa Pagaruyung merupakan replika Istana Minagkabau. Bangunannya berbentuk sebuah rumah panggung berukuran besar dengan atap gonjong yang menjadi ciri khas dari arsitektur tradisional Minangkabau. Rumah panggung besar ini bertingkat tiga, dengan 72 tonggak yang menjadi penyangga utamanya. Terdapat 11 gonjong atau pucuk atap yang menghias bagian atas dari bangunan ini. Seluruh dinding bangunan ini dihiasi oleh ornamen ukiran berwarna-warni yang secara total terdiri dari 58 jenis motif yang berbeda. Bentuk atau motif ukiran ini ada yang berbentuk melingkar atau persegi.

Andika (2014) menyatakan ukiran ini banyak digunakan sebagai hiasan Rumah Gadang, biasanya ukiran Rumah Gadang ini berbentuk garis melingkar atau persegi, dengan motif seperti tumbuhan merambat, akar yang berdaun, berbunga, dan berbuah. Pola akar ini biasanya berbentuk lingkaran, akar berjajaran, berhimpitan, berjalinan, dan juga sambung menyambung. Motif lainnya yang dijumpai pada rumah gadang adalah geometri bersegi tiga, empat, dan genjang. Pada pembelajaran matematika, ukiran ini erat kaitannya dengan materi geometri bidang dan geometri fraktal. Seperti penelitian yang telah dilakukan Rahayu (2014) mengenai etnomatematika pada kerajinan anyaman Bali yaitu adanya penggunaan prinsip teselasi/pengubinan pada pola anyaman. Teselasi tersebut menggunakan satu jenis bangun geometri yaitu persegi panjang dan persegi.

D'Ambrosio (1985) memperkenalkan suatu istilah yaitu etnomatematika. Ia mengatakan bahwa matematika yang dibelajarkan di sekolah disebut dengan academic mathematics, sedangkan etnomatematika merupakan matematika yang diterapkan dalam kelompok budaya yang terdefinisi seperti masyarakat suku, kelompok buruh, anak-anak dari kelompok usia tertentu, kelas profesional, dan sebagainya. Sehingga dapat dikatakan bahwa etnomatematika merupakan matematika yang muncul dalam suatu kebudayaan tertentu. Enomatematika dianggap sebagai lensa untuk memandang dan memahami matematika sebagai produk budaya. Budaya yang dimaksud mengacu pada masyarakat, tempat, tradisi, cara mengorganisir, menafsirkan, konseptualisasi, dan memberikan makna terhadap dunia fisik dan sosial (Ascher, 1991).

Proses pembelajaran matematika yang dibutuhkan saat ini adalah pembelajaran yang kontekstual dan realistik dengan menggunakan metode yang bervariasi. Hasil penelitian Pangestu dan Santi (2016) menunjukkan bahwa terdapat korelasi yang cukup tinggi antara pengaruh pembelajaran matematika yang realistik terhadap kesenangan belajar siswa. Dengan demikian, upaya ini dapat mempengaruhi minat siswa untuk mempelajari matematika yang dapat ditemukannya dalam kehidupan sehari-hari. Jika kita lihat di negara lain, Uloko dan Imoko (2007) mengatakan bahwa keberhasilan negara Jepang dan Tionghoa dalam pembelajaran matematika karena mereka menggunakan Etnomatematika dalam pembelajaran matematikanya. Menurut Gerdes (1994) Etnomatematika adalah matematika yang diterapkan oleh 
kelompok budaya tertentu, kelompok buruh/petani, anak-anak dari masyarakat kelas tertentu, kelas-kelas profesional, dan lain sebagainya. Berdasarkan definisi ini, disimpulkan bahwa etnomatematika memiliki pengertian yang lebih luas dari hanya sekedar etno (etnis) atau suku.

Hakekatnya matematika merupakan teknologi simbolis yang tumbuh pada keterampilan atau aktivitas lingkungan yang bersifat budaya. Dengan demikian, matematika seseorang dipengaruhi oleh latar budayanya, karena yang mereka lakukan berdasarkan apa yang mereka lihat dan rasakan. Bishop (1991) Budaya akan mempengaruhi perilaku individu dan mempunyai peran yang besar pada perkembangan pemahaman individual, termasuk pembelajaran matematika sesungguhnya telah menyatu dengan kehidupan masyarakat itu sendiri. Dalam rangka mengakomodasi peran etnomatematika dalam pembelajaran, guru matematika perlu menempatkan diri mereka sebagai fasilitator dan menempatkan siswa sebagai mitra sehingga peserta aktif dalam berbagi informasi bukan penerima pasif dari penyajian informasi.

Oleh sebab itu, para pakar etnomatematika berpendapat bahwa pada dasarnya perkembangan matematika sampai kapanpun tidak terlepas dari budaya dan nilai yang telah ada pada masyarakat maka penelitian etnomatematika perlu mendapat ruang. Berdasarkan uraian di atas, maka penelitian ini berjudul "Eksplorasi Etnomatematika Rumah Gadang Minangkabau Sumatera Barat". Khususnya tentang bentuk rumah gadang dan seni ukir (motif ukir) rumah gadang.

\section{METODE PENELITIAN Jenis Penelitian}

Jenis penelitian ini adalah penelitian eksploratif. Arikunto (2006) menjelaskam "penelitian eskploratif merupakan penelitian yang bertujuan untuk menggali secara luas tentang sebab-sebab atau hal-hal yang mempengaruhi terjadinya sesuatu". Sedangkan pendekatan yang digunakan dalam penelitian ini adalah pendekatan etnografi yaitu pendekatan yang bertujuan menyelidiki dan mendapatkan deskripsi serta analisis mendalam tentang suatu kelompok kebudayaan berdasarkan penelitian lapangan (fieldwork) dalam periode waktu tertentu secara intensif. Pendekatan ini memusatkan usaha untuk menemukan bagaimana masyarakat mengorganisasikan budaya tersebut dalam pikiran mereka dan kemudian menggunakannya dalam kehidupan sehingga ada dalam pikiran manusia. Metode penelitian yang dilakukan adalah wawancara.

\section{Waktu dan Tempat Penelitian}

Waktu penelitian dilakukan selama 4 bulan dimulai dari bulan April 2018 sampai Agustus 2018 di Museum Adityawarman Padang, Sumatera Barat, Rumah Gadang Istano Basa Pagaruyung Kecamatan Tanjung Emas, Kota Batusangkar, Kabupaten Tanah Datar Sumatera Barat, dan Seribu Rumah Gadang, Solok Selatan (informan). Peneliti meneliti tentang bagaimana bentuk rumah gadang dan seni ukir (motif ukir) rumah gadang.

\section{Instrumen}

Instrumen penelitian berupa kuisoner melalui wawancara yang diberikan kepada pemuka adat yakni niniak mamak, cadiak pandai, alim ulama, bundo kanduang, praktisi seni ukir yang memahami tentang seluk beluk bentuk rumah gadang dan motif ukiran rumah gadang. 
FIBONACCI : Jurnal Pendidikan Matematika dan Matematika. Vol. ( ), pp: .

\section{Prosedur dan Teknik Penelitian}

Penelitian ini diawali dengan melakukan survei pada tempat dilakukannya penelitian, penyusunan instrumen penelitian, menentukan jadwal penelitian, dan proses pelaksanaan penelitian dengan memberikan instrumen. Pengumpulan data dilakukan dengan metode wawancara (kuisoner), observasi dan dokumentasi tentang bagaimana bentuk rumah gadang dan motif ukiran rumah gadang. Pada dasarnya data yang akan dianalisis dalam penelitian ini berdasarkan hasil observasi, wawancara, dan dokumentasi yang mengaitkan bagaimana budaya yang terdapat di minangkabau mengandung unsur matematika. Analisis data yang akan dilakukan adalah analisis taksonomi. Analisis taksonomi memusatkan perhatian dan menjabarkan secara rinci pada domain tertentu yang sangat berguna untuk menggambarkan fenomena atau masalah yang menjadi sasaran penelitian. Analisis taksonomi dilakukan untuk membuat kategori dari simbol-simbol budaya yang ada pada kebudayaan yang diteliti.

\section{HASIL DAN PEMBAHASAN \\ Bentuk Rumah Gadang Minangkabau}

Bagi masyarakat Minang, rumah adat Minangkabau (rumah gadang) merupakan simbol tradisi sekaligus tempat untuk melaksanakan berbagai kegiatan keluarga besar pemilik rumah atau lazim disebut satu perut (paruik). Mulai dari proses perencanaan, pencarian bahan, tata cara membangun, pilihan model sampai ornamen dekorasi rumah gadang mengandung makna dan falsafah. Konsep matematika sebagai hasil aktivitas merancang bangunan, mengukur, memuat pola, serta berhitung dapat diungkap dari pembuatan rumah adat.

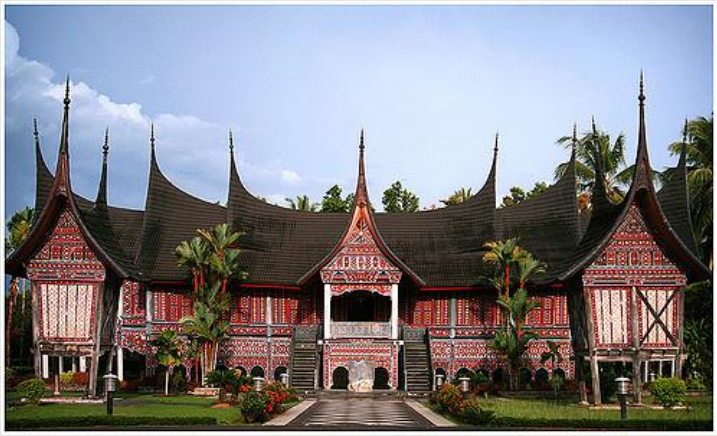

\section{Gambar 1. Rumah Adat Minangkabau}

Bentuk dasarnya, rumah gadang itu persegi empat yang tidak simetris yang mengembang ke atas. Atapnya melengkung tajam seperti bentuk tanduk kerbau, sedangkan lengkung badan rumah Iandai seperti badan kapal. Bentuk badan rumah gadang yang segi empat yang membesar ke atas (trapesium terbalik) sisinya melengkung kedalam atau rendah di bagian tengah, secara estetika merupakan komposisi yang dinamis. Jika dilihat pula dari sebelah sisi bangunan (penampang), maka segi empat yang membesar ke atas ditutup oleh bentuk segi tiga yang juga sisi segi tiga itu melengkung ke arah dalam, semuanya membentuk suatu keseimbangan estetika yang sesuai dengan ajaran hidup mereka.

Jika dilihat dan segi fungsinya, garisgaris rumah gadang menunjukkan penyesuaian dengan alam tropis. Atapnya yang lancip berguna untuk membebaskan endapan air pada ijuk yang berlapis-lapis itu, sehingga air hujan yang betapa pun sifat curahannya akan meluncur cepat pada atapnya. Bangun rumah yang membesar ke atas, yang mereka sebut silek, membebaskannya dan terpaan tampias. Kolongnya yang tinggi memberikan hawa yang segar, terutama pada musim panas. Di samping itu rumah gadang dibangun berjajaran menurut arah mata angin dari utara ke selatan guna membebaskannya dari panas matahari serta terpaan angin. Jika dilihat secara keseluruhan, arsitektur rumah 
gadang itu dibangun menurut syarat-syarat estetika dan fungsi yang sesuai dengan kodrat atau yang mengandung nilai-nilai kesatuan, kelarasan, keseimbangan, dan kesetangkupan dalam keutuhannya yang padu.

Sebenarnya terdapat beberapa tipe rumah gadang, tetapi yang paling dikenal adalah rumah gadang bagonjong. Rumah adat ini memiliki ciri khas berupa bentuk atap yang menyerupai tanduk kerbau. Konsep matematika dalam pembangunan, mekipun dahulu masyarakat Minangkabau belum mengenal materi dasar konstruksi bangunan seperti halnya yang sekarang diajarkan pada pendidikan formal (seperti konsep siku-siku, simetris, persegi panjang, maupun konsep geometri lainnya), tetapi mereka dapat membangun bangunan yang megah dan tahan lama jika dibandingkan dengan bangunan zaman sekarang.

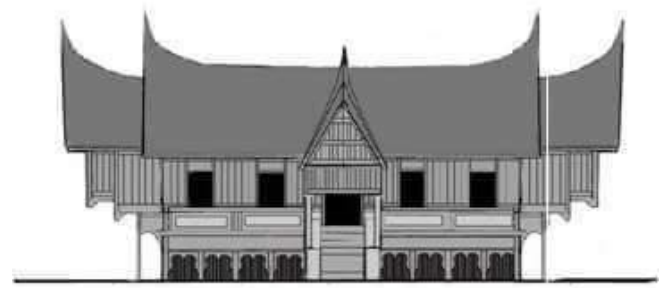

\section{Gambar 2. Rumah Gadang bergonjong Lima}

Makna jumlah atap gonjong rumah gadang Minangkabau mempunyai ciri khas atap berbentuk runcing yang disebut gonjong. Jumlah gonjong pada rumah gadang ternyata tidak selalu sama (berbeda). Rumah gadang di Solok Selatan mempunyai jumlah gonjong yang berbeda, dua gonjong hingga paling banyak 14 gonjong. Menurut pemerhati budaya minang, Ir. Hasmurdi Hasan (dalam video youtube), jumlah gonjong memiliki makna tertentu. Rumah gadang bergonjong dua berarti rumah warga biasa, rumah bergonjong empat berarti pemilik rumah seorang datuak, rumah bergonjong enam berarti punya koordinator datuak atau pemimpin adat tertinggi, jika gonjong lebih dari enam buah bukan berarti strata lebih tinggi justru balik lagi dari bawah.

Dilihat dari bentuk rumah gadang, masyarakat Minangkabau telah mengimplementasikan salah satu ilmu matematika, yaitu Geometri dalam pembangunan bagian-bagian bangunan rumah adat diantaranya model bangun datar, meliputi: persegi, persegi panjang, trapesium, segitiga, segitiga samakaki, segitiga samasisi, segilima, lingkaran serta belah ketupat, model bangun ruang, meliputi: kubus, balok, dan tabung, model sifat matematis, meliputi: sifat simetris, fraktal, dan konsep tranlasi (pergeseran).

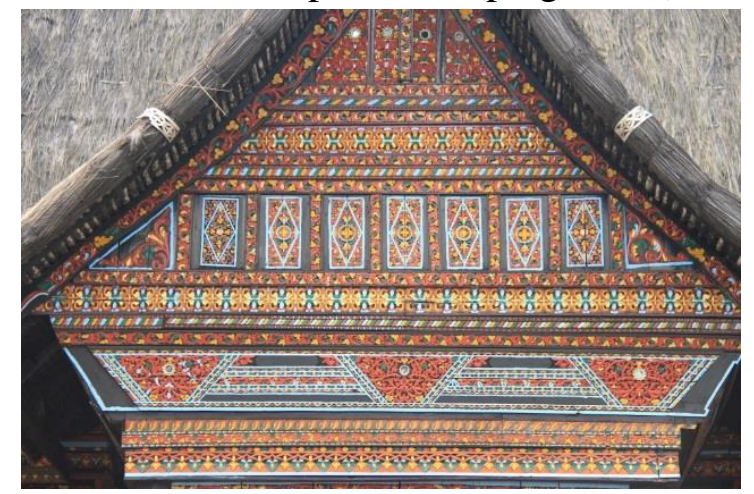

Gambar 3. Model Bangun Datar Pada Ornamen Ukiran

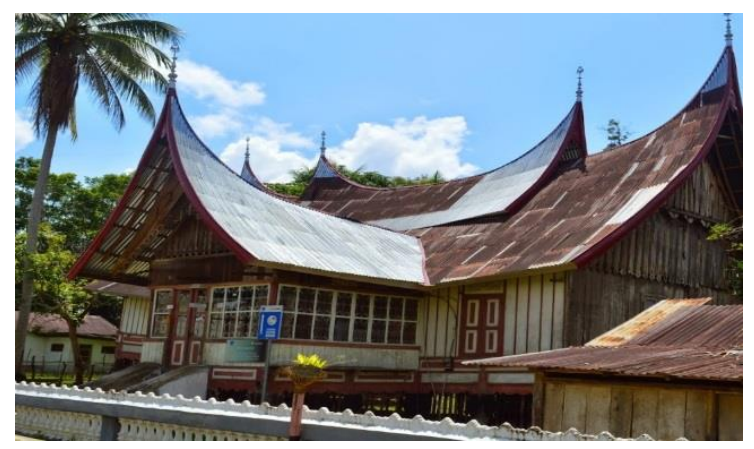

\section{Gambar 4. Rumah Masyarakat Minangkabau}

Pada gambar 4 di atas, terlihat bahwa terdapat konsep/aturan matematika pada jenjang/tangga rumah gadang, yaitu konsep/aturan Trigonometri dalam 
FIBONACCI : Jurnal Pendidikan Matematika dan Matematika. Vol. ( ), pp: .

menentukan berapa ukuran panjang jenjang/tangga.

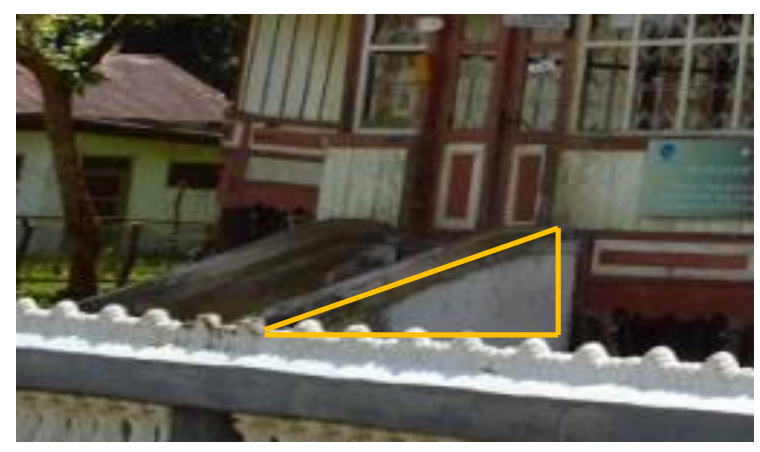

Gambar 5a

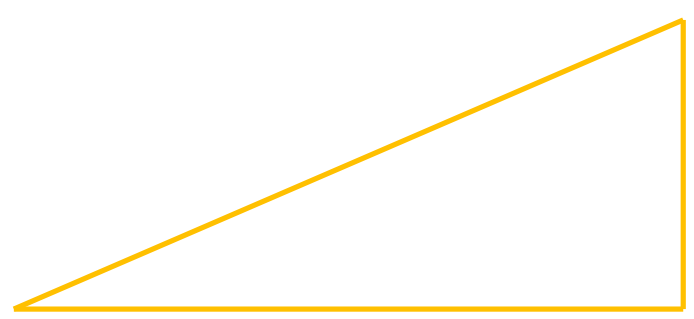

Gambar 5b

Dalam segitiga siku-siku tersebut dapat ditentukan enam buah perbandingan. Keenam perbandingan itu disebut perbandingan trigonometri pada segitiga siku-siku.

$$
\begin{aligned}
\sin \alpha^{\circ} & =\frac{\text { sisi di depan sudut } \alpha^{\circ}}{\text { sisi miring }} \\
\cos \alpha^{\circ} & =\frac{\text { sisi di samping sudut } \alpha^{\circ}}{\text { sisi miring }} \\
\tan \alpha^{\circ} & =\frac{\text { sisi di depan sudut } \alpha^{\circ}}{\text { sisi di samping sudut } \alpha^{\circ}} \\
\cot \alpha^{\circ} & =\frac{\text { sisi di samping sudut } \alpha^{\circ}}{\text { sisi di depan sudut } \alpha^{\circ}} \\
\sec \alpha^{\circ} & =\frac{\text { sisi miring }}{\text { sisi di samping sudut } \alpha^{\circ}} \\
\operatorname{cosec} \alpha^{\circ} & =\frac{\text { sisi miring }}{\text { sisi di depan sudut } \alpha^{\circ}}
\end{aligned}
$$

Dengan menggunakan konsep trigonometri tersebut kita dapat menentukan berapa kemiringan sudut yang terbentuk pada tangga/jenjang baik dari dasar (sudut elevasi) maupun dari dasar pintu (sudut delevasi).

\section{Ukiran Rumah Gadang Minangkabau}

Dinding rumah gadang terbuat dari kayu dan bagian belakangnya terbuat dari bambu. Kayu yang digunakan untuk membentuk dinding tersebut merupakan kayu pilihan. Kayu tersebut di bentuk menjadi papan. Dinding yang terbuat dari papan tersebut di pasang secara vertikal. Pada setiap sambungan antara papan yang satu dengan yang lain diberi bingkai. Pada jendela dan pintu juga terdapat bingkai yang terbuat dari papan. Bingkai tersebut di pasang dengan lurus. Semua papan dan bingkai ini dipenuhi oleh ukiran. Tidak hanya pada dinding, jendela atau pintu saja, tiang rumah gadang juga sering di ukir dengan berbagai macam gaya ukiran. Sehingga dapat dikatakan, ukiran tersebut merupakan hiasan yang dominan dalam bangunan rumah gadang minangkabau.

Ukiran yang di bentuk tersebut merupakan ragam hiasan bidang. Setiap ukiran pada bagian-bagian di rumah gadang mempunyai ciri khas dan makna tersendiri. Ukiran tersebut juga merupakan sebuah karya seni di minangkabau. Ukiran tersebut bersumber dari motif alam, yang berkaitan dengan falsafah alam yang dianut oleh orang minangkabau. Bukan berarti ukiran tersebut dijadikan sebagai bentuk kepercayaan atau sakral maupun sebagai bentuk pemujaan, tetapi ukiran tersebut semata-mata di tampilkan sebagai karya seni yang bernilai hiasan.

"Alam Takambang Jadi Guru" sebagai falsafah orang minangkabau sangat 
mempengaruhi bentuk dan gaya tampilan ukiran rumah gadang. Biasanya motif ukiran bersumber dari akar tumbuhan merambat. Akar tumbuhan merambat itu di sebut akar yang berdaun, berbunga, dan berbuah. Variasi susunan akar merupakan pola inti ukiran tersebut. ada pola akar berlingkaran, berjajaran, berhimpitan, berjalin, dan bersambung atau sambungmenyambung.

Penamaan ukiran tersebut disesuaikan dengan bentuk polanya. Nama-nama tersebut seperti "kaluak paku, pucuak rambuang, saluak laka, jalo, jarek, itiak pulang patang, dan saik galamai”. Setiap nama dari ukiran tersebut memiliki makna ajaran minangkabau. Penamaan dan pemakaian ukiran tersebut yaitu, "kaluak paku' diartikan sebagai ajaran anak dipangku kemenakan dibimbing. "pucuak rabuang" diartikan sebagai ajaran yang praktis yaitu "ketek baguno, gadang tapakai". "saluak laka" diartikan sebagai lambang kekerabatan di minangkabau yang saling berkaitan. "jalo" melambangkan sistem pemerintahan yang di tuangkan datuak parpatih nan sabatang atau aliran bodi caniago. "jarek" melambangkan sistem pemerintahan yang di ciptakan oleh datuak katumanggungan atau aliran koto piliang. "itiak pulang patang" diartikan sebagai sebuah ketertiban anak-kemenakan. "saik galamai" melambangkan ketelitian. Bentuk ukiran lain yaitu "si kambang manih" yang menggambarkan keramahan. Ragam Ukiran Minangkabau tersebut adalah:

1. Kaluak Paku Kacang Balimbiang

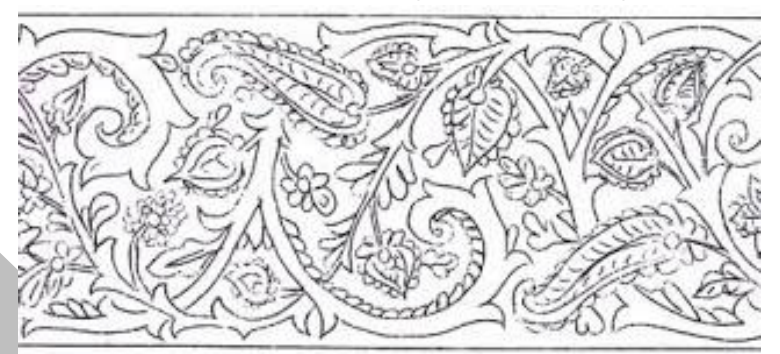

2. Lumuik Hanyuik

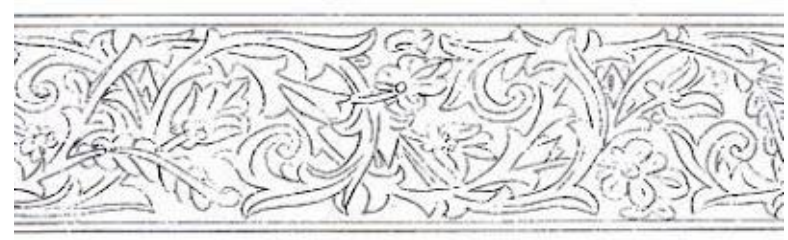

3. Bungo Panca matohari jo rantak malam

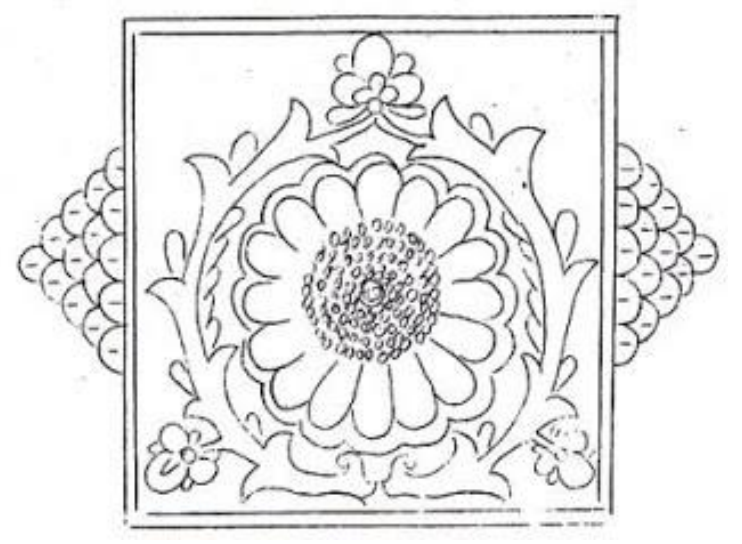

4. Singo Mandongkak jo Takuak Kacang Goreng

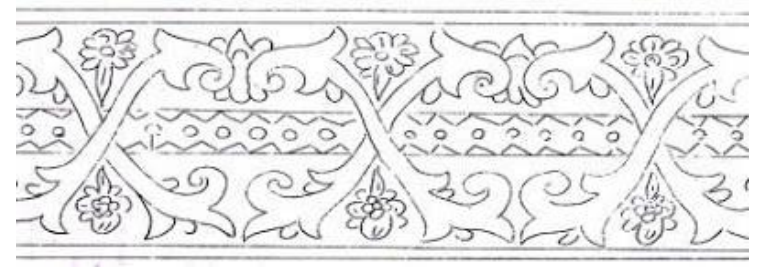

5. Carano Kanso

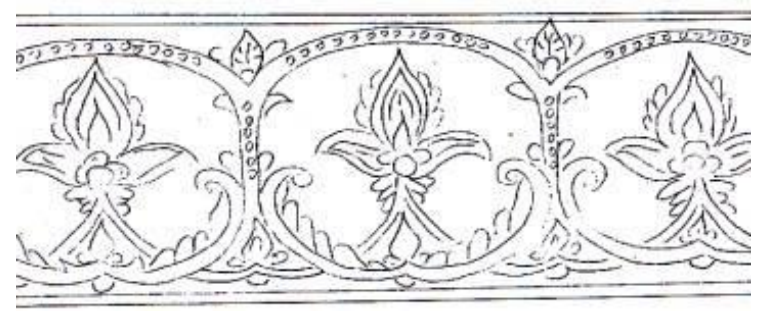

6. Siriah Gadang

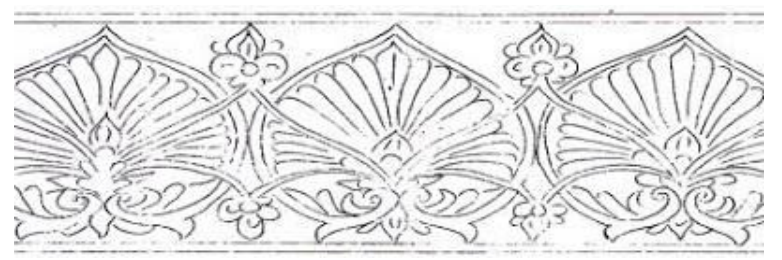

7. Bada Mudiak Itiak Pulang Patang

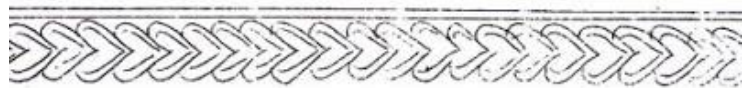


Yulia Rahmawati Z, Melvi Muchlian : Eksplorasi Etnomatematika Rumah Gadang Minangkabau Sumatera Barat

FIBONACCI : Jurnal Pendidikan Matematika dan Matematika. Vol. ( ), pp: .

\section{Tatandu Manyasok Bungo jo Buah Nibuang}

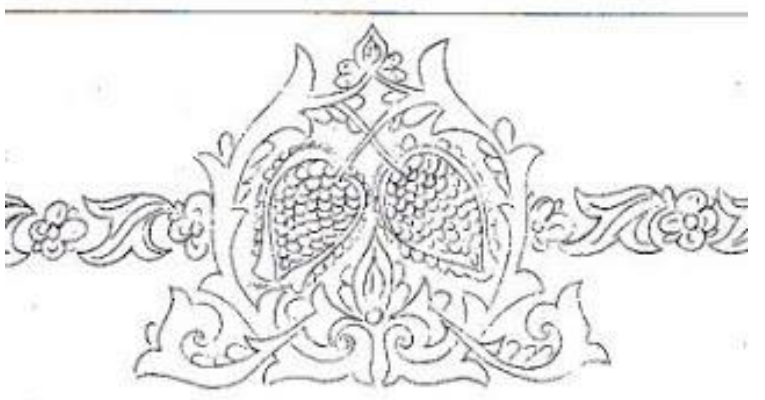

\section{Buah Palo Patah}

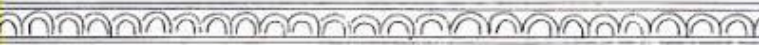

\section{Taji Siarek}

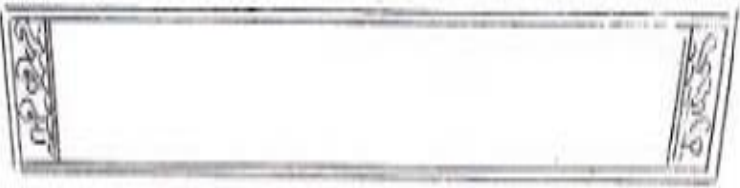

11. Paruah Anggang

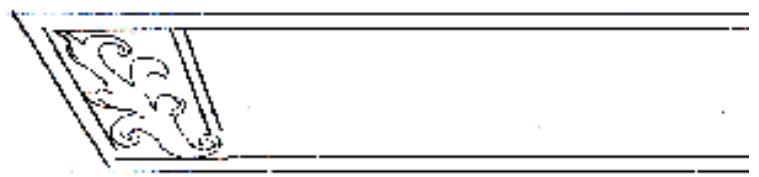

\section{Salangko}

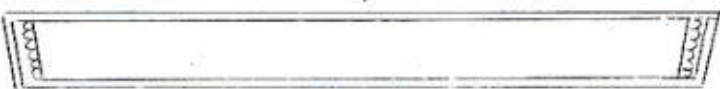

\section{Aka Tangah Duo Ganggang}

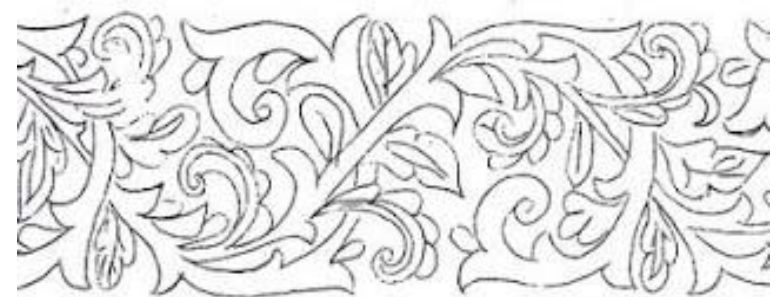

14. Kuciang Lalok jo Saik Galamai

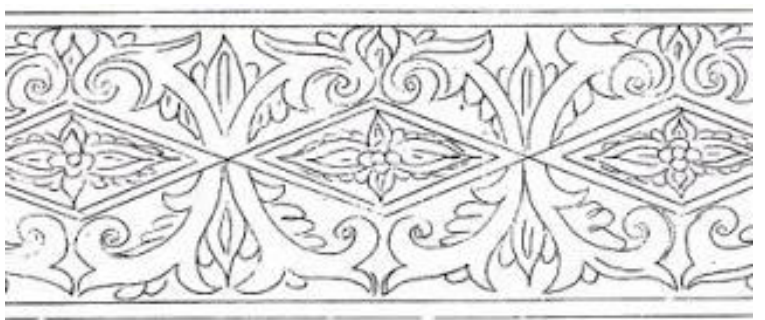

15. Pesong Aia ba Abuih

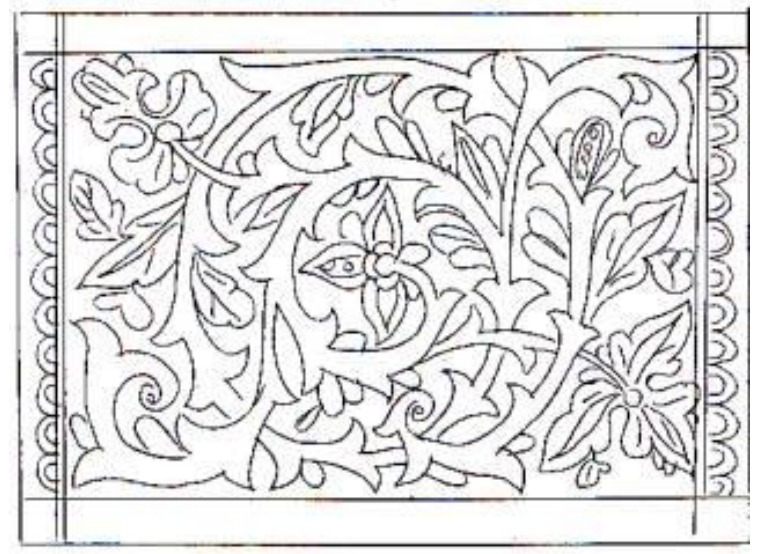

16. Sikumbang Manih 1

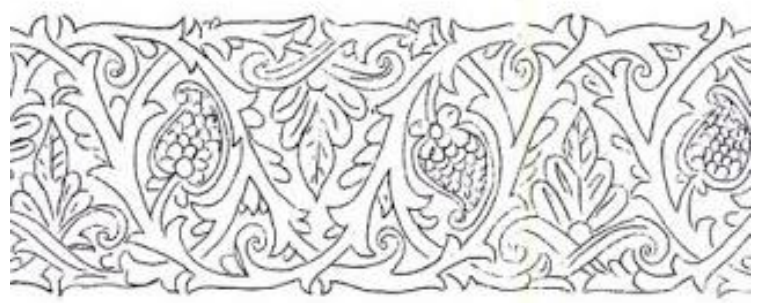

17. Sikumbang Manih 2

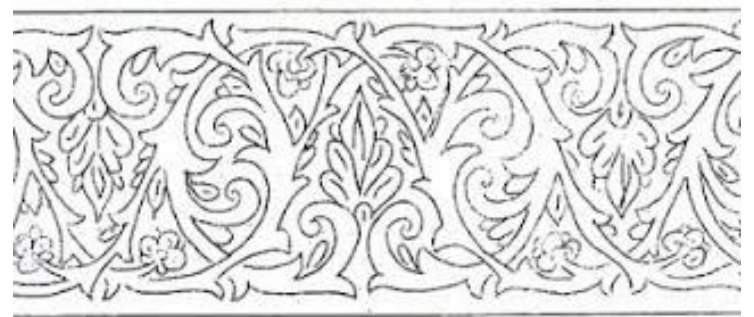

18. Sikumbang Manih 3

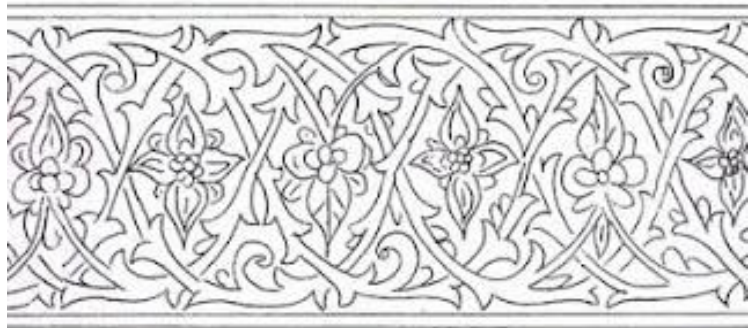

19. Sikumbang Manih 4

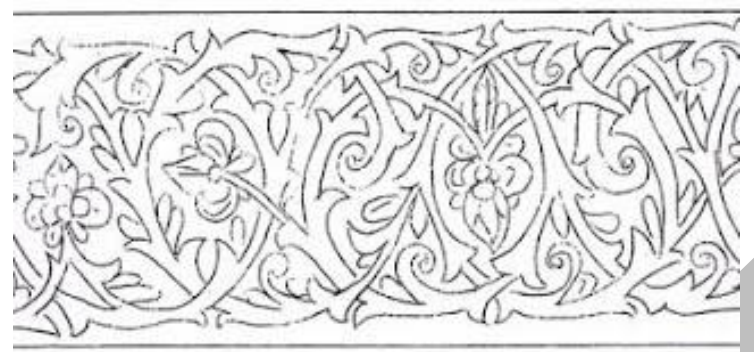




\section{Sikumbang Manih 5}

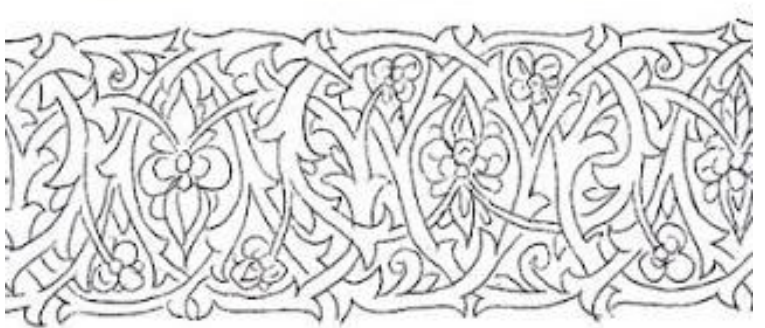

\section{Lapiah Batang Jarami}

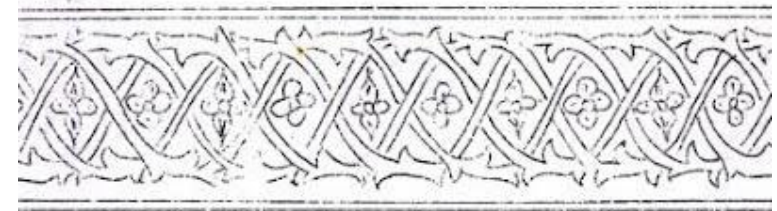

\section{Aka Duo Ganggang}

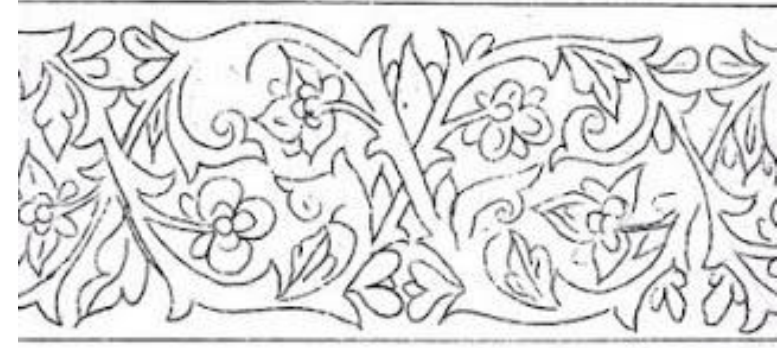

\section{Ruso Balari Dalam Ransang}

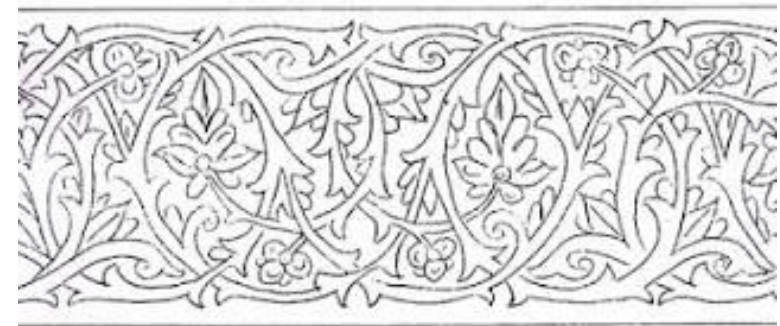

24. Bungo Duo Tangkai jo Buah Pinang

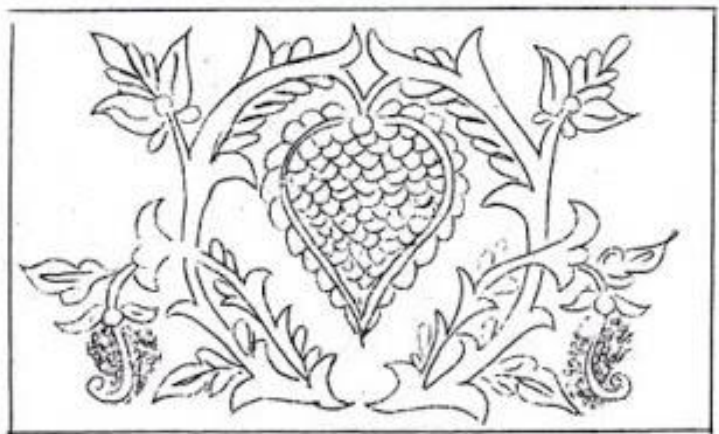

Konsep matematika sebagai hasil aktivitas dalam membuat pola yang dapat diungkapkan dari motif ukiran dinding rumah gadang diantaranya konsep lingkaran, garis lurus dan garis lengkung, simetris, refleksi, dilatasi, translasi, serta rotasi.

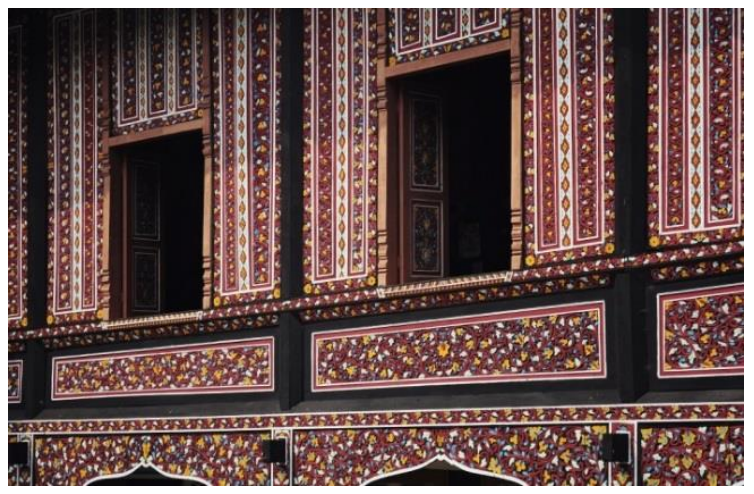

Gambar 6a

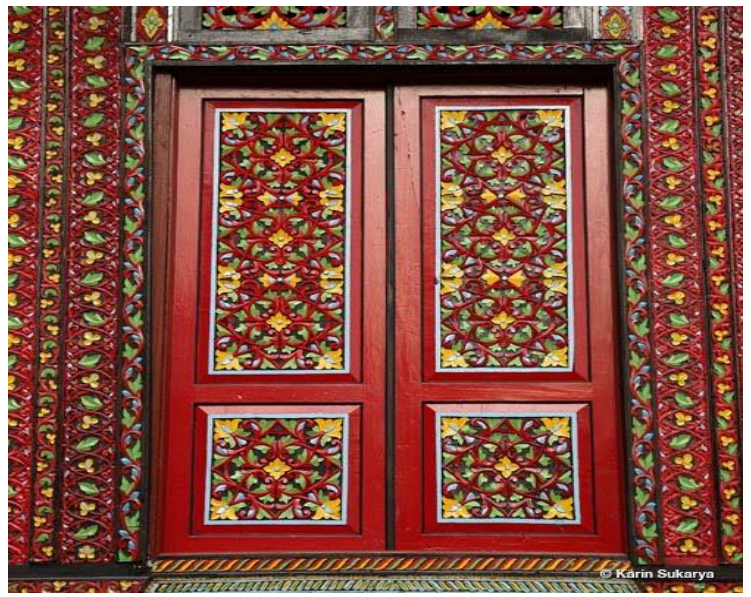

Gambar 6b

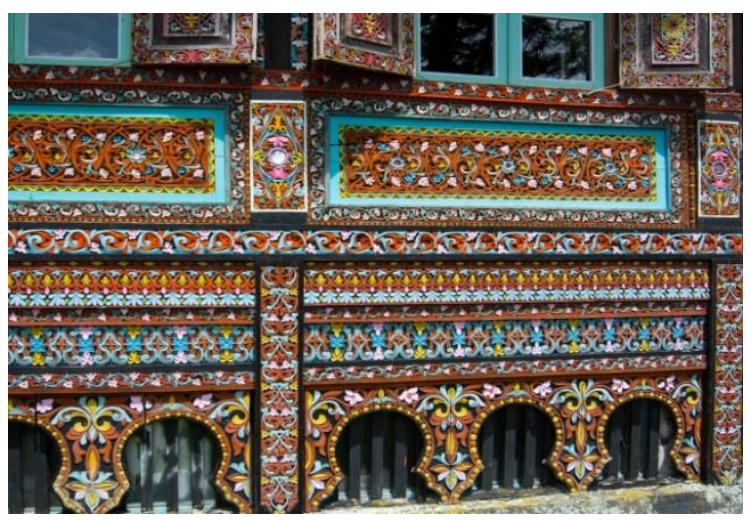

Gambar 6c

Ragam Ukir Khas Minangkabau pada Dinding Bagian Luar dari Rumah Gadang 
FIBONACCI : Jurnal Pendidikan Matematika dan Matematika. Vol. ( ), pp: .

Pada dasarnya ukiran pada Rumah Gadang merupakan ragam hias pengisi bidang dalam bentuk garis melingkar atau persegi. Motifnya umumnya tumbuhan merambat, akar yang berdaun, berbunga dan berbuah. Pola akar biasanya berbentuk lingkaran, akar berjajaran, berhimpitan, berjalinan dan juga sambung menyambung. Cabang atau ranting akar berkeluk ke luar, ke dalam, ke atas dan ke bawah. Disamping motif akar, motif lain yang dijumpai adalah motif geometri bersegi tiga, empat dan genjang. Motif daun, bunga atau buah dapat juga diukir tersendiri atau secara berjajaran.

Fraktal adalah benda geometris yang kasar pada segala skala, dan terlihat dapat "dibagi-bagi" dengan cara yang radikal. Beberapa fraktal bisa dipecah menjadi beberapa bagian yang semuanya mirip dengan fraktal aslinya. Fraktal dikatakan memiliki detil yang tak hingga dan dapat memiliki struktur serupa diri pada tingkat perbesaran yang berbeda. Pada banyak kasus, sebuah fraktal bisa dihasilkan dengan cara mengulang suatu pola, biasanya dalam proses rekursif atau iteratif. Seperti pola yang ada pada ukiran rumah gadang Minangkabau yang terdapat pengulangan suatu pola.

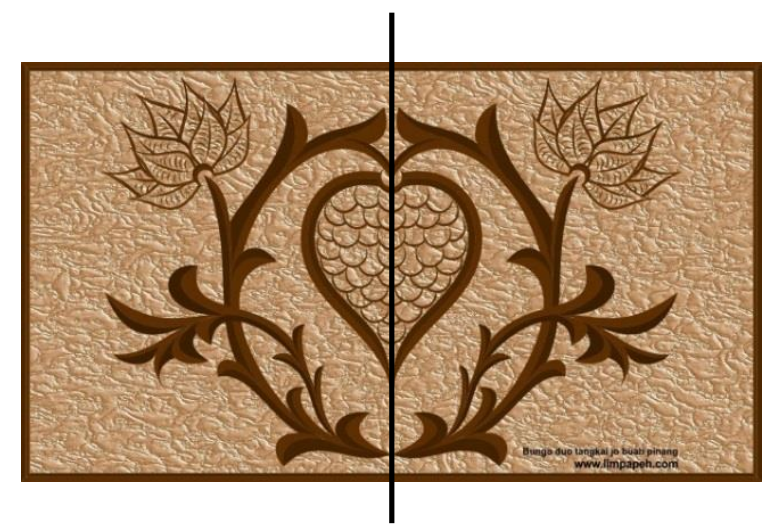

Gambar 6a

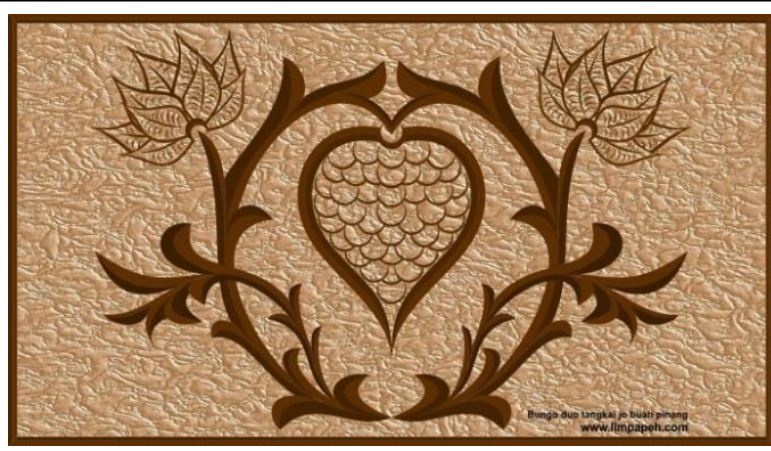

\section{Gambar 6b}

Pembuatan motif ukiran Bungo Duo Tangkai jo Buah Pinang diawali dengan pola dasar lingkaran. Setelah itu, dilukis pola daun yang merambat dan bunga yang kembang. Dari pola tersebut terlihat adanya kesimetrisan antara pola kanan dan kiri (Gambar 6a).

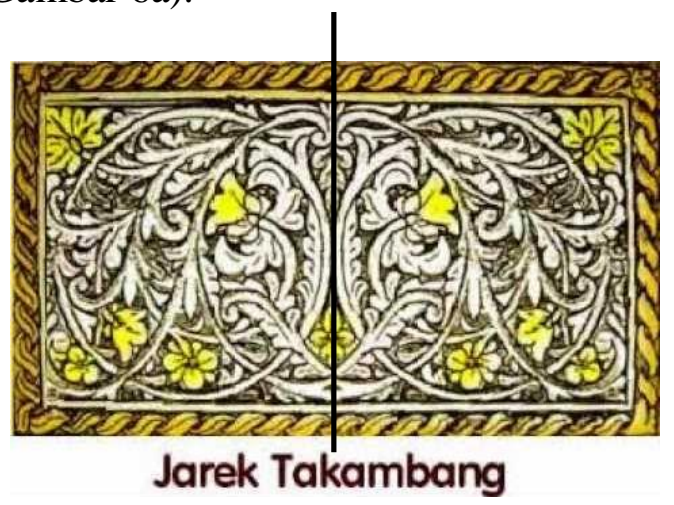

\section{Gambar 6c}

Gambar 6c memperlihatkan motif ukiran jarek takambang memiliki pola dasar lingkaran dari motif daun dan bunga yang melingkar berjalin dan sambung meyambung. Dari motif terseut terlihat baha ada pengulagan pola yang menyebabkan terjadinya geometri fraktal.

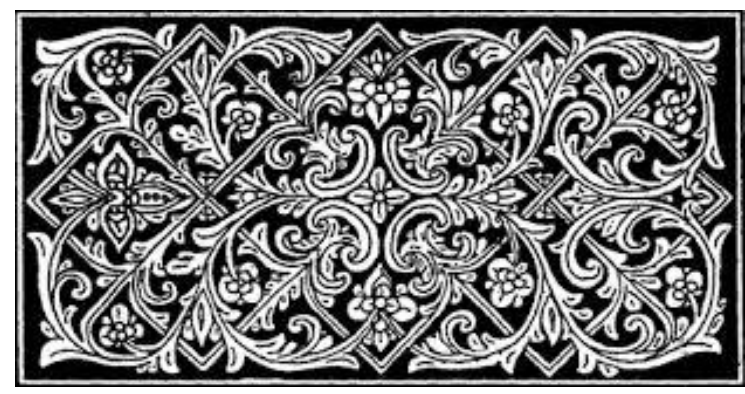

Gambar 6d 


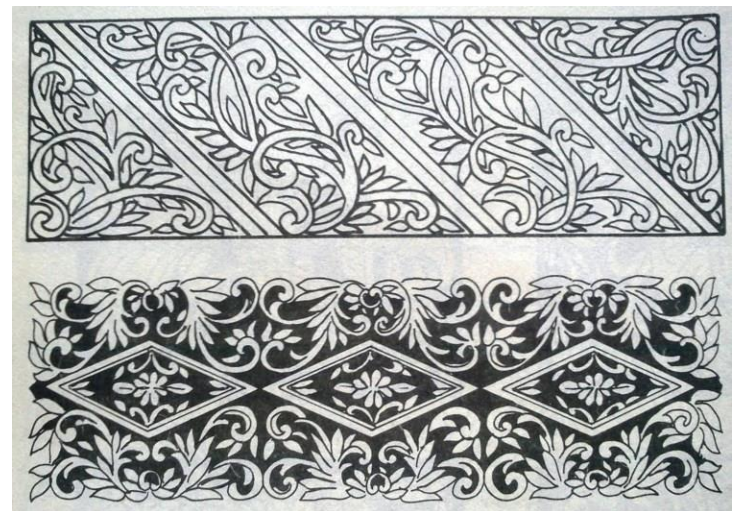

\section{Gambar 6e}

Beberapa unsur matematika lain yang ada dalam pola ukiran ini antara lai megenai garis, antara lain: garis vertikal dan horizontal, garis sejajar, dan garis berpotongan. Selain itu, terdapat unsur simetris, bangun datar seperti: persegi, segitiga, jajargenjang, lingkaran, dan belah ketupat.

Keberadaan geometri fraktal menunjukkan bahwa matematika bukanlah subjek yang kering dan datar, tetapi merupakan suatu subjek yang indah dan dapat menghasilkan karya-karya yang memiliki citra seni dan nilai intelektual yang tinggi. Geometri ini menghasilkan keindahan yang sangat luar biasa. Warisan leluhur berupa seni ukir Minangkabau ini telah menunjukkan bahwa nenek moyang kita juga mengenal keindahan lewat geometri fraktal matematika. Hanya saja mungkin mereka belum menyadari bahwa hasil karyanya merupakan geometri fraktal.

\section{SIMPULAN}

Berdasarkan hasil dan pembahasan yang telah dipaparkan sebelumnya, dapat disimpulkan bahwa hasil penelitian menunjukkan dalam aktivitas pembuatan rumah gadang minangkabau terdapat unsur dan konsep matematika yang digunakan. Tanpa mempelajari teori tentang konsepkonsep matematika tersebut, masyarakat Minangkabau telah menerapkan konsep matematika dalam kehidupan sehari-hari menggunakan etnomatematika. Terbukti adanya bentuk etnomatematika masyarakat minangkabau yang tercermin melalui berbagai hasil aktivitas matematika yang dimiliki dan berkembang di masyarakat minangkabau, meliputi: 1) aktivitas membuat rancangan pembangunan rumah gadang; dan 2) aktivitas membuat pola ukiran pada motif ukiran dinding rumah gadang.

\section{DAFTAR PUSTAKA}

Andika, Raka Prasetyo. 2014. Uraian Tentang Atap Dan Deskripsi Rumah-Rumah Adat Seluruh Indonesia. http://rakaraperz.blogspot.co.id/2014/08/Uraian-tentang-atap-dandeskripsi-rumah-rumah-adat-seluruh-indonesia.html. di unduh tanggal 20 Februari 2018.

Arikunto, Suharsimi. 2006. Prosedur Penelitian. Jakarta : Rineka Cipta.

Ascher, M. 1991. Ethnomathematics: A Multicultural View of Mathematical Ideas. New York: Capman \& Hall.

Bishop, J.A.1991. The Simbolic Technology Calet Mathematics its Role in Education. Bullatin De La Societe Mathematique, De Belgique, T,XLIII.

D'Ambrosio, U. 1985. Ethnomathematics and its place in the history and pedagogy of mathematics.

http://www.math.utep.edu/Faculty/pmdelgado2/Math1319/History/DAmbrosio.pdf. di unduh tanggal 20 Februari 2018.

Gerdes, P.1994. Reflection on Ethnomatematics. For the Learning of Mathematiccs.

Koetjaraningrat. 1985. Pengantar Ilmu Antropologi. Jakarta: Aksara Baru. 
Pangestu, P \& Santi, A.U.P. 2016. Pengaruh Pendidikan Matematika Realistik Terhadap Suasana Pembelajaran Yang Menyenangkan Pada Pelajaran Matematika Sekolah Dasar. Fibonacci: Jurnal Pendidikan Matematika dan Matematika. Vol. 2 (2), pp: 5871.

Rahayu P, Kadek. 2014. Etnomatematika di Balik Kerajinan Anyaman Bali. Jurnal Matematika Vol. 4 No. 2, Desember 2014. Denpasar: Universitas Mahasaraswati Denpasar.

Rachmawati, Inda. 2012. Eksplorasi Etnomatematika Masyarakat Sidoarjo. Ejournal. Surabaya: FMIPA UNESA. di unduh tanggal 20 Februari 2018.

Ratna, Nyoman Kutha. 2005. Sastra dan Cultural Studies: Representasi Fiksi dan Fakta. Yogyakarta: Pustaka Pelajar.

Rosa, M. \& Orey, D. C. 2011. Ethnomathematics: the cultural aspects of mathematics. Revista Latinoamericana de Etnomatemática, 4(2). 32-54.

Uloko, E.S \& Imoko, B.I. 2007. Pengaruh Ethnomatematics Mengajar Pendekatan dan Jenis Kelamin terhadap Prestasi Siswa dalam Lokus. J. Natl. Assoc. Sci. Humanit. Educ, Res. 5(1).

Wahyuni, Astri. et. al. 2013. Peran Etnomatematika dalam Membangun Karakter Bangsa. Prosiding Seminar Nasional Matematika dan Pendidikan Matematika, ISBN: 978979-16353-9-4. Yogyakarta: FMIPA UNY. 